\title{
改重回帰分析による血液中の一酸化炭素へモグロビンの分 析に不適切な試料の検出
}

\author{
三井利幸 ${ }^{\mathrm{a}}{ }^{*}$, 肥田宗政 ${ }^{\mathrm{b}}$ \\ a 数值解析研究所, 数值解析研究所, $\overline{\mathrm{T}} 475-0833$ 愛知県半田市花園町 $1-18-28$

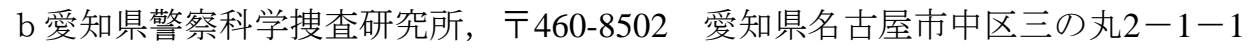

(Received October 31,2005 ; Accepted March 14,2006)

既知試料の測定值の補正值を説明変数, 未知試料の測定值の補正值を目的変数として重回帰式を作成 し, 非分離分析を行う改重回帰分析(Different calculation method of regression analysis, DCR)を利用 して, 得られた重回帰式から未知試料の補正值と計算值の差を比較することにより分析に不適切な試料 を検出し, 誤った分析結果を提示寸る危険性を排除する方法について検討した。その結果, PCR や PLS のような従来の方法では困難であった分析に不適切な試料の検出が容易にでき, 誤判定を防止すること が可能となった。今回は, この方法を腐敗や熱変性を受けた可能性のある血液中の一酸化炭素へモグロ ビン $(\mathrm{CO}-\mathrm{Hb} \%)$ の定量に応用した。その結果, 51 試料中完全に分析に不適切な 5 試料, 分析にやや問題 のある 8 試料が検出され，誤判定を未然に防止することができた。この方法は，血液のように変性する 試料だけではなく，分析目的成分以外の不純物が混合している試料に対しても忘用可能である。

\footnotetext{
キーワード：改重回帰分析, 分析不適切試料の検出, 補正值と計算值, 重回帰係数, 血液中一酸化炭素 ヘモグロビン濃度
}

\section{序論}

分析化学の分野では, 試料の前処理, 分離方法, 分析結果の信頼性の向上等を目的とした研究が数 多く行われている。しかしながら，分析の対象とな る試料 (未知試料) や分析機器から得られた測定值 が分析を行うのに適したものであるか否かの検討
はあまり行われていない。特に, 腐敗, 熱, 薬品等 で変性を受けた可能性のある血液や臟器等の生体 試料は, 分析を行う以前に試料が分析に適したもの であるか否かの検討は必要不可欠なことである。通 常,臨床検查等の試料は採取後短時間の間に分析に 着手するので問題はないが，犯罪に関係した試料は 分析着手までにかなり長時間を経過したものがあ り, 未知試料が分析に適しているか否かの検討を行

*tmitsui@js4.so-net.ne.jp 
わないと, 得られた分析結果の判断を誤り,犯罪行為 を見過ごしてしまう危険性がある。しかしながら， 現状では未知試料が分析に適したものか否かを明 確に判断する方法がなく, 経験的に分析に不適当な 試料を排除しているに過ぎない。そこで，すでに報 告 ${ }^{1 \sim 2)}$ した改重回帰分析(DCR)が，未知試料の測定 值（補正值）に対応する計算值を計算で求めている ことに注目し, 補正值と計算值の差の大きさとその 範囲域から, 分析に不適当な試料を排除する方法に ついて検討した。

\section{改重回帰分析 (DCR)による分析不適当試料 の排除方法}

DCRは，重回帰分析 ${ }^{3 \sim 7)}$ で用いられている既知試 料の目的変数の代わりに未知試料の説明変数 $\left(y_{a}\right.$, $\alpha=1,2,3, \ldots, n)$ を目的変数として使用し, 未知試 料の個々の説明変数 $\left(y_{\alpha}\right)$ とその計算值 $\left(Y_{\alpha}, \alpha=1,2\right.$, $3, \ldots, n)$ との残差 $\left(e_{\alpha}, e_{\alpha}=y_{\alpha}-Y_{\alpha}, \quad \alpha=1,2,3\right.$, $\ldots, n)$ 二乗和が最小となるように重回帰式を作成 している。従って，m個の既知試料と未知試料が持 つ個の補正值から, 未知試料の $\mathrm{n}$ 個の補正值と計算 值が最小となるように作成された重回帰式にm個の 既知試料の $\alpha$ 番目の各補正值を代入すれば，それに 対応する未知試料の $\alpha$ 番目の計算值が得られるこ とになる。このことは, 作成された重回帰式にm個 の既知試料の $\alpha=1,2,3, \ldots, n$ を順次代入していけ ば未知試料の $\alpha=1,2,3, \ldots, n$ までの計算值が得ら れることになる。今回は, 吸光光度法で測定した吸 収スペクトルを用いる血液中の一酸化炭素へモグ ロビン $(\mathrm{CO}-\mathrm{Hb} \%)$ の定量時における分析不適切試料 の検出にこの方法を応用した。

方法は，未知試料の401個の補正值から得られる 吸収スペクトル（補正值吸収スペクトル）と最も近 似した計算值から得られる吸収スペクトル（計算值 吸収スペクトル）を，既知試料のCO-Hb\%が $0 \%$ と 100\%の補正值の吸収スペクトルから計算值吸収ス ペクトルを合成することである。このとき，合成し た吸収スペクトルを作成するのに使用した既知試 料のCO-Hb\%が $0 \%$ と $100 \%$ の補正值吸収スペクトル の使用割合が重回帰式の係数で示されているので, 係数から未知試料のCO-Hb\%が定量できる。さらに, 既知試料のCO-Hb\%が $0 \%$ と $100 \%$ の吸収スペクトル だけで未知試料の計算值吸収スペクトルを作成し ているので，CO-Hb\%と還元へモグロビン(Hb)以外 の成分が共存していれば,未知試料の補正值吸収ス ペクトルと計算值吸収スペクトルは近似していな い波長領域が生じる。この近似していない波長領域 の範囲幅と, 補正值と計算值との差の大きさから,
分析に適する試料か否かの判断が可能となる。

従って, 測定值吸収スペクトルと計算值吸収スペ クトルを比較すれば，使用した既知試料だけで未知 試料の混合成分の定量が可能か否かの判断ができ る。今回のようにCO-Hb\%を定量する場合は，変性 を受けていない血液中のへモグロビンは, CO-Hbと ハイドロサルファイトナトリウムで酸素へモグロ ビン $\left(\mathrm{O}_{2}-\mathrm{Hb} \%\right)$ を還元したHbしか存在していないの で，CO-Hbと Hbを既知試料として使用すれば，血 液中のCO-Hb\%が非分離で定量可能となる。しかし ながら, 未知試料が変性を受けていれば, CO-Hbと Hb以外の物質が共存し, 補正值吸収スペクトルと計 算值吸収スペクトルとの差が大きな波長領域範囲 が広くなり，CO-Hb\%の定量は不可能となる。

このことは, 未知試料が既知試料に含まれている 成分だけから構成されていれば，既知試料の補正值 を重回帰式に代入して得られた未知試料の計算值 は，未知試料の補正值と極めて類似した数值となり， 重回帰式の相関係数(R)は限りなく 1.000 に近づくこ とになる。しかし, 未知試料が既知試料の成分以外 のものを含有していれば，その成分が持つ補正值の 領域に相当する部分の計算值と補正值との差は大 きくなり, さらに重回帰式の相関係数 $(R)$ も低下する。 従って，血液試料のように未知試料が腐敗等で変性 していれば,当然CO-Hb\%とHb以外の成分が混合し ているので, 変性の程度に比例して未知試料の補正 值と計算值との差は大きくなり, その波長領域範囲 幅も広くなる。

すでに述べたように，目的とする未知試料の計算 值 $\left(Y_{\alpha}\right)$ は, 複数の既知試料の測定值を説明変数, 未知試料の測定值 $\left(y_{\alpha}\right)$ を目的変数として, 従来から 行われている方法で計算 ${ }^{5 ）}$ し得られた（1）式に示 したような重回帰式から求められる。

$Y_{\alpha}=b_{1} x_{1 \alpha}+b_{2} x_{2 a}+\ldots+b_{m} x_{m_{a}}+b_{0}$

但し, $\alpha=1,2,3, \ldots, n)$

$\mathrm{m}$ 個の既知試料から得られた重回帰式の係数 $b_{1}$, $b_{2} \ldots, b_{m}$ は, 各既知試料が持つn個の補正值に対して 同一なので，係数から未知試料の計算值を得るため の既知試料の使用割合が求められる。

例えば，CO-Hb\%を定量するような場合は,既知試 料が 2 個，測定值が 401 個 $(m=2, n=401)$ なので， 未知試料の 401 個の計算值は， 2 個の既知試料の 401 個の測定值を（2）式に示した重回帰式に順次代入 していけば得られることになる。

$Y_{\alpha}=b_{1} x_{1 \alpha}+b_{2} x_{2 \alpha}+b_{0}$

但し, $\alpha=1,2,3, \ldots, 401$

このことは，（2）式の重回帰式に各既知試料の最 初の測定值 $\left(x_{11}, x_{21}\right)$ を代入すれば, 未知試料の最初の 補正值に対応する計算值 $\left(Y_{1}\right)$ が得られることを意味 している。同様の方法で 2 個の既知試料の測定值を 
順次（2）式に代入していけば，未知試料の401個 の補正值に対応するn個の計算值が得られることに なる。

DCRでは，計算に用いる説明変数（測定值,補正 值）の数が多いほど，未知試料の測定值とその計算 值との近似性を細かく検討していることになる。既 知試料から得られた計算值は,この条件の下では未 知試料の補正值と最も近似した計算值であり, 説明 変数の数が多いほどより細かい間隔で, 未知試料の 補正值と計算值を最も近似させていることになる。 もしも，未知試料に既知試料以外の成分が混合して いれば,未知試料の補正值にはその成分の補正值が 加算されているので,補正值と計算值との差が拡大 することになる。

さらに，未知試料の補正值 $\left(y_{\alpha}\right)$ とそれに対応する 計算值 $\left(Y_{\alpha}\right)$ との残差が大きな領域は，未知試料と 類似したパターンを形成することが不可能な部分 となる。このような未知試料の補正值 $\left(y_{\alpha}\right)$ とそれに 対応する計算值 $\left(Y_{\alpha}\right)$ が大きく異なってくる領域は, この領域にスペクトルを持つ不純物が共存してい る可能性を示唆している。

\section{実験及び結果}

\section{1 測定値の補正}

DCRによる定量では，既知試料や未知試料の濃度 は正確にする必要はないが,既知試料や未知試料の 測定值の最大值と最小值は同一数值にしなければ ならない。そのために, DCRでは既知試料や未知試 料の測定值から, 最大值と最小值を示す測定值を選 択して, それらの数值で補正し, 最大值を 1.000 , 最小 值を 0.000 とした補正值を使用しなければならない。 従って, すべての試料の測定值は最小值が 0 , 最大 值が 1 の数值に補正される。血液中のCO-Hb\%を吸 光光度法で測定した測定值の補正方法は, まず未知 試料を測定し得られた401個の測定值から650 nmの 吸光度值を差し引き, $650 \mathrm{~nm}$ 補正值を 0 とした。次 いで450〜650 nm間で最大值を示した吸光度值で 401個の測定值を除した。同様の方法でCO-Hb\% が $0 \%$ と $100 \%$ の既知試料も補正した。実際の未知試料 の測定值,補正值,重回帰式から得られた計算値の吸 収スペクトルをFig. 1に示した。Fig. 1に示したよう に, 定量に不適切な試料は補正值と計算值の吸収ス ペクトルに明確な差が認められる。それに対し定量 に適した試料は, Fig. 2に示したように, 補正值と計 算值の吸収スペクトルはほとんど同一の吸収スペ クトルとなる。

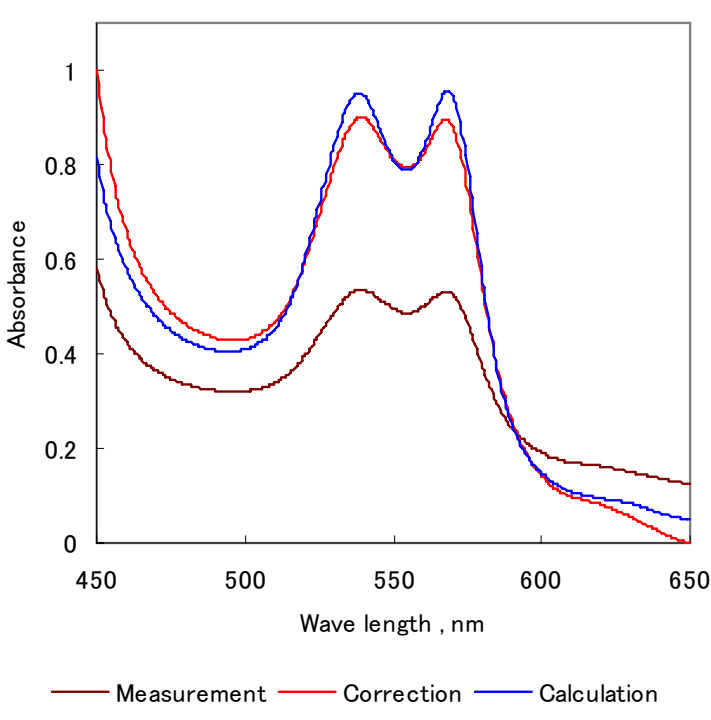

Fig.1 Measured, corrected, and calculated spectrum of unknown sample

401 measurement points were used for DCR.

Multiple regression expression:

$Y=0.0452 x_{1}+0.8715 x_{2}+0.0452 \quad \mathrm{R}=0.9897$

$x_{1}$ :CO-HB\% 0\%; $x_{1}$ :CO-Hb\% 100\%

\subsection{CO-Hb\%の分析に不適な未知試料の 抽出}

血液中には, $\mathrm{CO}-\mathrm{Hb}, \mathrm{O}_{2}-\mathrm{Hb}, \mathrm{Hb}$ が共存している ので， $\mathrm{O}_{2}-\mathrm{Hb}$ を還元してHbにする必要があり，さ らに測定值の最小值を 0 , 最大值を 1 の数值に補正 しているので，測定值の最大吸光度が 0.400 未満の 場合は補正による拡大割合が大きくなり，生じた誤 差が定量結果に影響を与えることがある。従って， 可能な限り測定值の最大吸光度は0.400から 1.000 になるようにする必要がある。そのために, 約 $0.1 \mathrm{ml}$ の試料血液に約 $5 \mathrm{ml} 00.1 \%$ 炭酸ナトリウム水溶液 と約 $5 \mathrm{mg}$ の亜ジチオン酸ナトリウム (ハイドロサル ファイトナトリウム）を添加して濃度を調整し，約 10分間静置して $\mathrm{O}_{2}-\mathrm{Hb}$ を完全にHbに還元した後, 吸 光光度法で測定した。

吸光光度法は,光源にハロゲンランプ,測定波長領 域450〜650 nmを $0.5 \mathrm{~nm}$ 間隔,バンド幅 $2.0 \mathrm{~nm}$,ガラス セル幅10 mm,スキャン速度 $1000 \mathrm{~nm} / \mathrm{min}$ の条件で日 本分光製HV-530を用いて測定した。

分析に不適な未知試料の抽出は,未知試料の401 個の補正值を目的変数,CO-Hb\% が 0 \% と $100 \%$ の既 知試料の 401 個の補正值を説明変数として二元一次 の重回帰式を作成した。次いで, 得られた重回帰式に CO-Hb\% が0\%と $100 \%$ の既知試料の401個の補正值 
を順次代入し,未知試料の401個の計算值を求めた。 ついで，作成した重回帰式の相関係数(R)を読取り， さらに401個の未知試料の補正值と計算值との差の 絶対值を計算することで，未知試料がCO-Hb\%を定 量するのに適した試料であるか否かを判断した。

定量可能な未知試料の相関係数(R)の数值と補正 值と計算值の差のしきい值は,変性を受けていない 30 試料の測定結果から,相関係数(R)が0.999以上, 401 個全ての各補正值と計算值との差の絶対值が 0.01 未 満であれば,定量可能な試料と判断した。さらに変性 を受けていない血液を, 綿栓を施し容量約 $10 \mathrm{ml}$ の試 験管に入れた状態で， $55^{\circ} \mathrm{C}$ で5〜 10 分間加熱した 10 試料と $30^{\circ} \mathrm{C}$ で湿度 $90 \%$ の条件下で5〜 72時間放置し た10試料の測定結果から,相関係数(R)が0.999未満, 401個の補正值と計算值との差の絶対值が 0.01 以上 の場合は,試料は何らかの原因で変性を受けている 可能性があるものと判断した。今回のCO-Hb\%の定 量は401個の補正值を用いているので, 相関係数(R) が0.999以上と高いしきい值になっているが,補正值 数が少ない場合はもつと相関係数 $(\mathrm{R})$ の数值が低く ても未知試料は分析に使用可能となる。従って,目的 とする試料が分析に適したものか否かの判断とな る相関係数(R)や補正值と計算值との差の絶対值の しきい值は,あらかじめ定量目的以外の成分の混合 していないことが明確な $3 〜 5$ 試料を測定して設 定しておく必要がある。なお,一度しきい值を設定す れば,再度しきい值を検討し直す必要はない。連続し て定量するような場合は,既知試料の測定は一週間 に一回程度行い,測定機器の立ち上げごとに測定す る必要はない。

実際にCO-Hb\%定量を目的として依頼された51 試料について,変性していないで分析結果が信用で きる試料,若干変性しているが高濃度のCO-Hb\%に ついての分析結果は比較的信用できる試料,変性が 著しく分析に使用不適な試料から得られた補正值 及び計算值の吸収スペクトルをFig.2, 3, 4に示した。 さらに,本来CO-Hb\%の定量分析に使用できない試 料を含めたDCRによるCO-Hb\%の定量結果をTable 1に示した。

Fig. 2 とTable 1の黒色で示した試料から明らかな ように, CO-Hb\%の定量に適した試料の重回帰係数 (R)はいずれも0.9991以上を示し, 401個の補正值と 計算值の絶対值の差も0.01以下と小さく, 測定值と 計算值の吸収スペクトルは重複した状態を示した。

それに対し, CO-Hb\%の定量に適さないTable 1の 赤色で示した試料の重回帰係数(R)は,いずれも0.989 以下を示した。さらに,Fig. 3からも明らかなように, 最も相関係数(R)が 0.9897 と高い試料番号 21 でも, 広 範囲の波長領域で補正值と計算值の差の絶対值が 0.05以上を示し，401個の補正值と計算值の吸収スペ
クトルの差が大きく異なった吸収スペクトルを示 した。特に試料番号24, 50は補正值と計算值の吸収 スペクトル間は極端に異なった吸収スペクトルを 示した。Fig. 5に示した, 変性を受けていない血液を $60^{\circ} \mathrm{C}$ で30分間加熱した試料と， $30^{\circ} \mathrm{C}$ で湿度 $90 \%$ の条 件下で 5 日間放置し腐敗させた試料による補正值 の吸収スペクトルの状態から,試料番号24は腐敗し ており, 試料番号50は熱で変性を受けているものと 推定された。

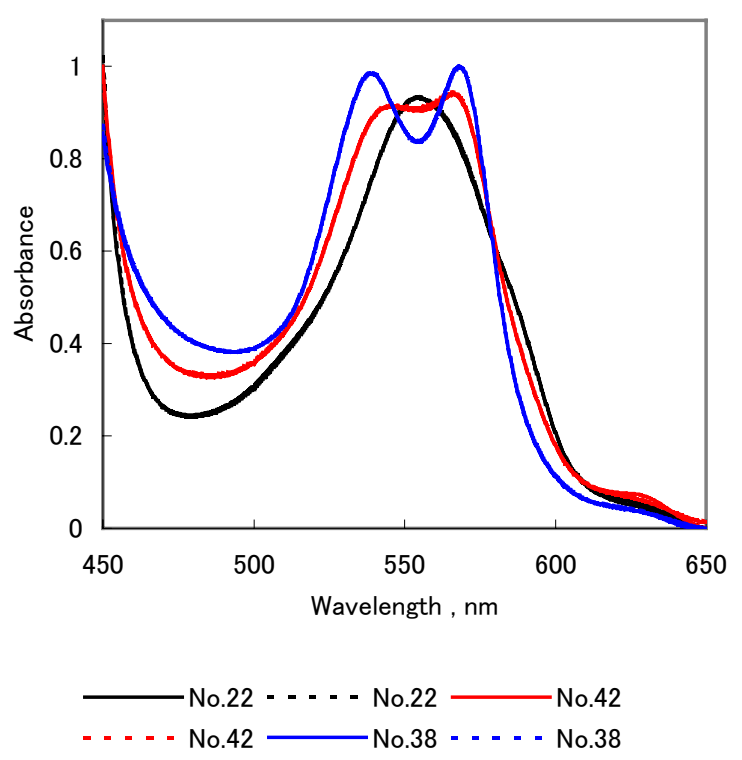

Fig. 2 The sample of very high approximation between correction value and calculated value

— : corrected value; _............ : calculated value The sample can be use for quantitative analysis.

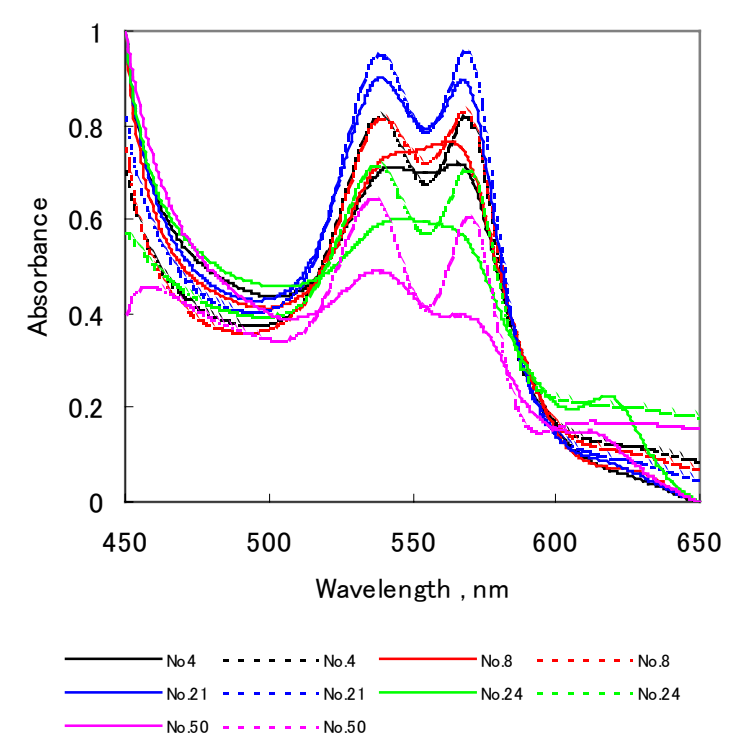

Fig. 3 The sample of no approximation between correction value and calculated value _ : corrected value; _............. : calculated value 
The sample can not be use for quantitative analysis.

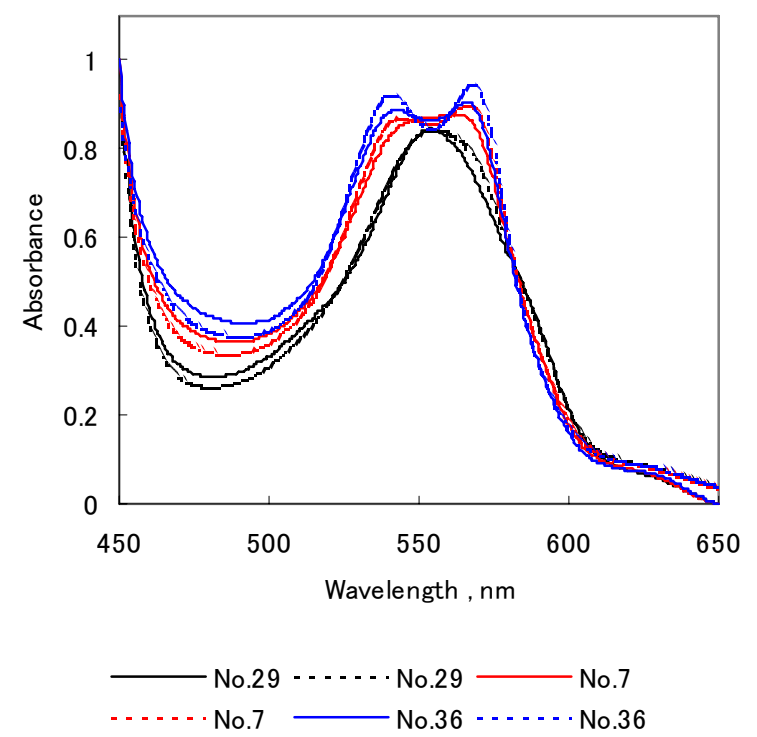

Fig. 4 The sample of approximation between correction value and calculated value

_ : corrected value; ............. : calculated value

The sample received a little change by heat or putrefaction. The analytical result needs cautions.

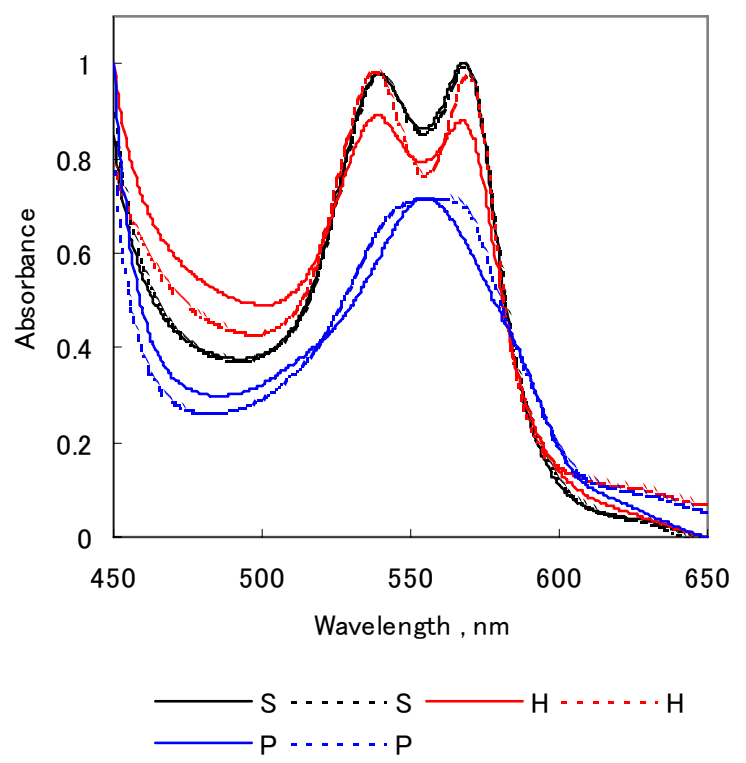

Fig. 5 The degenerate sample by heat or putrefaction S:unchanged sample; H:heated sample; P:putrefied sample

— : corrected value; $\quad$.............. : calculated value

Fig. 4に示した試料はTable 1の青色で示した試料 に該当するもので，相関係数 $(\mathrm{R})$ が $0.990 \sim 0.999$ 未満 を示した。補正值と計算值の差の絶対值は, 相関係
数(R)が 0.9988 と最も高い試料番号 14 でも部分的に 0.04を示し, Fig. 3やTable 1の赤色で示した試料ほど 強く変性を受けていないものと考えられたが, 得ら れた CO-Hb\%の定量值の信頼性は若干低下するも のと考えられた。特に,試料番号 $1,14,29$ のうに, CO-Hb\%の低い試料については,他の死亡原因も検 討することが重要となる。

Table 1 The analytical result of CO-Hb\%

\begin{tabular}{crrrrr}
\hline Sample No. & $\mathrm{R}$ & $\mathrm{CO}-\mathrm{Hb} \%$ & Sample No. & $\mathrm{R}$ & $\mathrm{CO}-\mathrm{Hb} \%$ \\
\hline 1 & 0.9977 & 25.00 & 27 & 0.9999 & 79.75 \\
2 & 0.9996 & 88.64 & 28 & 0.9999 & 80.46 \\
3 & 0.9994 & 70.27 & 29 & 0.9948 & 17.89 \\
4 & 0.9416 & 97.51 & 30 & 0.9998 & 89.24 \\
5 & 0.9996 & 75.84 & 31 & 0.9999 & 88.41 \\
6 & 0.9995 & 12.61 & 32 & 0.9997 & 96.40 \\
7 & 0.9957 & 49.99 & 33 & 0.9991 & 7.63 \\
8 & 0.9647 & 80.60 & 34 & 0.9997 & 89.68 \\
9 & 0.9997 & 10.06 & 35 & 1.0000 & 89.70 \\
10 & 0.9998 & 78.10 & 36 & 0.9945 & 69.70 \\
11 & 0.9998 & 11.55 & 37 & 0.9997 & 91.05 \\
12 & 0.9972 & 73.23 & 38 & 1.0000 & 86.60 \\
13 & 0.9997 & 87.71 & 39 & 0.9991 & 65.79 \\
14 & 0.9988 & 9.74 & 40 & 1.0000 & 52.30 \\
15 & 1.0000 & 77.59 & 41 & 0.9983 & 36.90 \\
16 & 0.9992 & 90.12 & 42 & 0.9998 & 45.38 \\
17 & 0.9999 & 79.55 & 43 & 1.0000 & 74.55 \\
18 & 0.9998 & 85.97 & 44 & 0.9985 & 95.40 \\
19 & 1.0000 & 0.00 & 45 & 1.0000 & 82.16 \\
20 & 0.9995 & 84.15 & 46 & 0.9995 & 87.97 \\
21 & 0.9897 & 95.07 & 47 & 0.9929 & 104.78 \\
22 & 0.9998 & 9.68 & 48 & 0.9998 & 89.92 \\
23 & 0.9999 & 24.42 & 49 & 0.9999 & 87.31 \\
24 & 0.8519 & 121.54 & 50 & 0.7421 & 198.49 \\
25 & 0.9995 & 89.85 & 51 & 0.9995 & 7.32 \\
26 & 0.9996 & 85.06 & & & \\
\hline $\mathrm{R}:$ Coefficient of correlation & & &
\end{tabular}

Black: The quantity analysis result can be trusted.

Blue: The obtained analysis result needs to judge carefully.

Red: The quantity analysis result can not be trusted.

Table 1に示したCO-Hb\%の定量は,すでに報告 ${ }^{2)}$ したように，未知試料の401個の補正值を目的変 数,CO-Hb\%が $0 \%$ の既知試料の補正值を $\mathrm{x}_{1}, \mathrm{CO}-\mathrm{Hb} \%$ が100\%の既知試料の補正值を $\mathrm{x}_{2}$ として，（3）式の ような重回帰式を作成して行った。

$Y_{\alpha}=b_{1} x_{1 \alpha}+b_{2} x_{2 \alpha}+b_{o}$

但し, $\alpha=1,2, \ldots, 401$

試料中のCO-Hb\% $\left(C_{1}\right)$ は $(4)$ 式から計算される。 $C_{1}=b_{1} /\left(b_{1}+b_{2}\right)$

例えば,試料番号 2 からは次に示すような重回帰 式が得られ，

$Y=0.1169 x_{1 \beta}+0.9122 x_{2 \beta}-0.0156 \quad \mathrm{R}=0.9996$

CO-Hb\%が0 \%の $x_{1}$ の係数0.1169 と CO-Hb\%が100\% の $x_{2}$ の係数 0.9122 力ら,

$C=(0.1169 \times 0+0.9122 \times 100) /(0.1169+0.9122)=$ $88.640 \fallingdotseq 88.64$ 但し,C : CO-Hb\%

となる。 
個人差 ${ }^{8)}$ があるために明確ではないが一酸化炭素 による中毒死のCO-Hb\%の最低值は，検査した381 名の結果から50～55\%程度と考えられている。従つ て,Table 1に示したCO-Hb\%が45\%未満の試料番号 1,6, 9, 11, 19, 22, 23, 33, 51は一酸化炭素中毒死以外 の死亡原因を明確にする必要がある。特に,試料番号 19は焼死体でCO-Hb\%が0.00\%であることから,殺人 放火の可能性が大きい。試料番号11,51は焼身自殺で あることが第三者によって証明されているが,試料 番号 $1,6,9,22,23,33$ は放火殺人の可能性も否定で きない。やや変性を受けた可能性のあるTable 1の青 色で示した試料については,試料番号14, 29は一酸化 炭素中毒死以外で死亡した可能性が高い。試料番号 7, 41は試料がやや変性を受けた可能性があるため に,一酸化炭素中毒死か否かの判断が難しく慎重に 他の死亡原因を検討する必要がある。試料番号 12 , 36,44, 47はCO-Hb\%の定量結果の信頼性は低いが, 一酸化炭素中毒死である可能性は高いものと推定 される。試料が熱や腐敗で大きく変性しているTable 1の赤色で示した試料については, CO-Hb\%を定量す ることが誤りで,定量結果は全く信用できない。参考 として，試料番号 $4,8,21,24,50$ にいて，補正值か ら計算值を差し引いた吸収スペクトルを，熱及び腐 敗で変性した試料の補正值から計算值を差し引い た吸収スペクトルと比較したところ，試料番号 4,8 , 50は熱変性を受けた試料, 試料番号21, 24は腐敗し た試料と類似した吸収スペクトルが得られた。

CO-Hb\%の定量は犯罪性の有無を決定するのに極 めて重要な要素であり, CO-Hb\%の数值によって, 薬 物や毒物の検査や, 病死の可能性を含めて解剖等を 行う必要があるかどうかの判断しなければならな い。科学捜査においては,分析で得られたCO-Hb\%の 数值だけでなく, 数值から犯罪性の可能性の有無や 死に至るまでの状況等の綿密な考察が重要である。

\section{考察}

すでに報告 ${ }^{1 \sim 2)}$ したように,DCRは分離すること が困難な試料中の個々の成分を,検量線を作成する ことなく短時間で定量することが可能である。しか し,同一の分析機器から得られた測定結果が比較的 異なっているような化合物については極めて有効 な方法であるが，測定結果が類似しているような化 合物が混合している場合は定量が困難となる。従っ て，不純物として試料中に混合している成分の測定 結果が,定量目的成分と極めて類似しているような
場合は,分析に不適当な試料の抽出をすることは困 難となる。

この方法は,血液等の生体試料のように試料自体 が変性するものだけでなく, 誤った測定条件で測定 したり,測定中にノイズ等の妨害が入ったり,不純物 が混合したりしていて正確な定量分析結果が得ら れないような試料の抽出をすることも可能である。

\section{結語}

DCRは既知試料と未知試料から得られる複数の 測定值を補正した補正值を使用して, 未知試料の補 正值と計算值との残差の二乗和が最小になるよう に計算している。従って，補正值と計算值の差及び 差の範囲域から分析に不適当な試料を抽出し分析 対象から除外することによって、分析結果の信頼性 を高めることが可能となった。今回は,この方法を CO-Hb\%の定量に応用し, 熱や腐敗で変性した血液 から誤ったCO-Hb\%の定量值を求める危険性を排除 することができた。

今後は，DCRを応用して,試料に含有されている 分析目的以外の成分の推定と, 分析機器やヒューマ ンエラーによる分析精度の低下を防止する分析方 法を開発していく予定である。

\section{文献}

［1］三井利幸, 奥山修司,肥田宗政 : 分析化学, 53, 773 (2004).

［2］三井利幸，奥山修司：J. Computer Aided Chemistry, 6, 23 (2005).

［3] 相島鉄郎：“ケモメトリックス”， (1992), （丸善）.

４４］宮下芳勝, 佐々木眞一：“ケモメトリックス 一化学パターン認識と多变量解析—”, (1995)，（共立出版）.

[5] 三井利幸 “ケモメトリックスの基礎と応用”, p 42, (アイピーシー).

［6]奥野忠一，久米均，芳賀敏郎，吉澤正：“多 変量解析法”，(1983)，（日科技連）。

［7]奥野忠一, 芳賀敏郎, 矢島敬二, 奥野千恵子, 橋本茂司，古河陽子：“続多変量解析法”， p 147(1981)，（日科技連）。

[8] 三井利幸, 伊藤稔 : 衛生化学, 36, 158 (1990). 


\title{
Exclusion of Unsuitable Blood Sample for Quantitative of Carbon Monoxide Hemoglobin Analysis Using Different Calculation Method of Regression Analysis (DCR)
}

\author{
Toshiyuki Mitsui $^{\mathrm{a}^{*}}$, Minesada Hida ${ }^{\mathrm{b}}$ \\ ${ }^{a}$ Data Analysis Laboratory, 1-18-18, Hanazono-cho, Handa-shi , Aichi 475-0833, Japan \\ ${ }^{\mathrm{b}}$ Criminal Investigation Laboratory, Aichi Prefecture Police H. Q., 2-1-1, Sannomaru, Naka-ku, Nagoya \\ 460-8502, Japan
}

The biochemistry sample extracted from the criminal spot may have received change by decomposition etc. An exact conclusion is not obtained from the result analyzed using such a sample, and may draw the mistaken conclusion from it. In order to avoid such a thing, it is necessary to investigate that whether a sample can use it for analysis

The different calculation method of regression analysis (DCR) was considered as the check method whether a sample is suitable for analysis objective. In this time, the analysis of $\mathrm{CO}-\mathrm{Hb} \%$ concentration in blood is applied, and how to eliminate an unsuitable sample to analysis was examined. The judgment method of the propriety analysis of a sample was performed from the difference of the range region and size between the correction value of a sample and the calculated value from DCR, and the correlation coefficient value of heavy regression was used for the judgment. When the difference of correction value and the calculated value from DCR was wide range and big, and the correlation coefficient of the multiple regression expression was less than 0.9991, it became clear that it is a sample unsuitable to analysis.

Keywords : Different calculate method of regression (DCR); Exclusion of unsuitable sample for quantitative analysis ; correction value and the calculated value ; Coefficient of the multiple regression expression ; concentration ( \% ) of carbon monoxide hemoglobin in blood

*tmitsui@js4.so-net.ne.jp 